\title{
ADSORPSI RADIONUKLIDA AM-241, CS-137 DAN SR-90 MENGGUNAKAN HASIL IMOBILISASI BENTONIT-ASAM HUMAT
}

\author{
KRIS TRI BASUKI ${ }^{*}$, MUZAKKY $^{* *}$ \\ *Sekolah Tinggi Teknologi Nuklir-BATAN \\ Jl Babarsari KP 6101/YKBB Yogyakarta 55281 \\ ** Pusat Teknologi Akselerator dan Proses Bahan-BATAN \\ Jl Babarsari KP1008 Yogyakarta 55010
}

\begin{abstract}
Abstrak
ADSORPSI RADIONUKLIDA AM-241, CS-137 DAN SR-90 MENGGUNAKAN HASIL IMOBILISASI BENTONIT-ASAM HUMAT. Telah dilakukan adsorsi Am-241, Cs-137 dan Sr-90 menggunakan hasil proses imobilisasi asam humat dengan bentonit (bentonit-asam humat). Tujuan penelitian ini adalah (1) melakukan pembuatan bahan adsorben dari hasil imobilsasi asam humat kedalam mineral bentonit, beserta karakterisasinya dengan spektroskopi infra merah dan difraktometer sinar-X dan (2) aplikasi adsorpsi Am-241, Cs-137, dan Sr-90 pada berbagai $\mathrm{pH}$. Hasil percobaan menunjukan bahwa imobilisasi bentonit-asam humat yang dilakukan dengan umpan 100 gr bentonit optimum pada berat asam humat $60 \mathrm{~g}$, kuat ion $0,1 \mathrm{M} \mathrm{NaNO}_{3}$, dan $\mathrm{pH}$ 2,5. Pada kondisi optimum bentonit dapat mengikat gugus $\mathrm{COOH}$ maksimum sebesar $75,2 \%$. Berdasarkan data spektroskopi infra merah dan difraktometer sinar-X, asam humat dapat termobilisasi kedalam mineral bentonit membentuk bahan paduan bentonit-asam humat. Aplikasi adsorpsi radionuklida Am-241, Cs-137 dan Sr-90, menunjukan bahwa bentonit-asam humat dapat mengadsorpsi padarentang $\mathrm{pH} 3$ hingga $\mathrm{pH} 10$. Melalui umpan masing-masing $0,001 \mathrm{mMol} / \mathrm{l}$, kuat ion $0,1 \mathrm{M} \mathrm{NaNO}_{3}$ dan $\mathrm{pH} 5$ ternyata bentonit-asam humat dapat mengadsorpsi 98,50\% - 99,1\% radionuklida Am-241, Cs-137 dan Sr-90
\end{abstract}

Kata kunci : imobilisasi, adsorpsi, spektroskopi infra merah, difraktometer sinar-X

\begin{abstract}
ADSORPTION OF AM-241, CS-137 AND SR-90 RADIONUCLIDES USING IMMOBILISATION PROCESS YIELDED OF HUMIC ACID INTO BENTONITE MINERAL (BENTONITE-HUMIC ACID). Adsorption of Am241, Cs-137 and Sr-90 radionuclides using immobilisation process yielded of humic acid into bentonite mineral (bentonite-humic acid) have been done. The aim of this study is (1) to conduct making of adsorbent material from immobilisation process yielded of humic acid into bentonite mineral, along with it's characterization with spectroscopy infra red and X-ray diffractometer and (2) adsorption application of $\mathrm{Am}-241, \mathrm{Cs}-137$ and Sr-90 at various $\mathrm{pH}$. Experiment result was shown conducted for immobilization of bentonite-humic acid were optimum at $100 \mathrm{~g}$ bentonite, $60 \mathrm{~g}$ humic acid, $0.1 \mathrm{M} \mathrm{NaNO}_{3}$ ionic strength, and $2.5 \mathrm{pH}$. At the optimum condition bentonite could be bind the functional $\mathrm{COOH}$ maximum equal to $75.2 \%$. Base on infra red spectroscopy and X-ray diffractometer data, it was showthat humic acid can immobilized into bentonite to form of bentonite-humic acid alloy. Application of
\end{abstract}


adsorption radionuclide of Am-241, Cs-137 and of Sr-90, showed that bentonitehumic acid can adsorp at the range of $\mathrm{pH} 3-10$. With the feed each of radionuclide $0,001 \mathrm{mMol} / 1,0,1 \mathrm{M} \mathrm{NaNO}_{3}$ ionic strength and $\mathrm{pH} 5$ in the bentonite-humic acid can adsorpted 98,50 - 99,1\% of Am-241, Cs-137 and Sr-90 radionuclides.

Keywords : immobilisation, adsorption, infra red spectroscopy, X-ray diffractometer

\section{PENDAHULUAN}

Terlepasnya radionuklida kedalam lingkungan merupakan salah satu indeks dari keberhasilan suatu instalasi nuklir. Selanjutnya terlepasnya radionuklida kedalam lingkungan dari instalasi nuklir merupakan masalah yang serius bagi keselamatan lingkungan, sehingga cepat atau lambat akan berdampak terhadap manusia ${ }^{[1]}$. Konvensional remediasi dari terkontaminasinya sedimen oleh radionuklida, biasanya dilakukan dengan cara mengambil, dimasukan kedalam container dan dipindahkan kelain tempat. Cara ini tidak hanya merusak lingkungan dan memerlukan biaya besar, juga mengakibatkan terkontaminasinya para pekerja melalui sistim pernapasan ${ }^{[2]}$.

Untuk itu dibutuhkan strategi alternative remediasi radionuklida yang aman bagi lingkungan dan para pekerja. Proses remediasi tersebut salah satunya adalah dengan cara penaburan bahan adsorpben selektif pada sedimen atau tanah yang tercemar ${ }^{[3,4]}$. Banyak faktor yang mempengaruhi terhadap mobilitas dan keberadaan radionuklida didalam sedimen. Beberapa radionuklida hasil fisi, akan teradsorpsi kedalam mineral dengan rendah organik seperti kaolinite tetapi akan segera terdesorpsi. Beberapa radionuklida juga dapat teradsorpsi kedalam mineral mica, illite, vermiculite dan smectite tetapi tidak segera terdesorpsi jika mineral mineral tersebut mengandung fraksi tanah liat ("Clay") dari tanah atau sedimen dengan jenis dan komposisi tertentu.

Berdasarkan Carver ${ }^{[3]}$, perlakuan terhadap sedimen yang terkontaminasi Cs-137 dan ditambahkan campuran mineral "illite-clay", ternyata dapat menurunkan derajat kontaminan 29\% terhadap tanaman jagung dan $42 \%$ pada kedelai. Kandungan tanah liat ("Clay") 20-30\% didominisasi oleh senyawaan humat yang berupa makromolekul mengandung gugus fungsional karboksil dan hidroksil. Dengan sifat hidrophobik, pengkelat, penukar ion dan kaya akan gugus oksigin donor diantara molekul senyawa humat, senyawa ini segera membentuk senyawa kompleks yang stabil dengan beberap unsur "Actinida" seperti Am-241 ${ }^{[4]}$. Berdasarkan Kumar $^{[1]}$ faktor transfer radionuklida dari tanah kedalam tanaman $\left(\mathrm{FT}_{\mathrm{SP}}\right)$ tidak hanya dipengaruhi oleh proses metabolisme tanaman itu sendiri tetapi, lebih didominisasi oleh karakterisasi tanah disekitarnya seperti $\mathrm{pH}$ dan 
kandungan material organik seperti senyawa humat. Sebagai makromolekul senyawa humat terdiri dari beberapa beberapa fraksi berat molekul dan terdistribusi sebagai koloid dengan 1000-50.000 Dalton. Dengan perbedaan fraksi tersebut, kemampuan dalam mengadsorpsi terhadap radioisotop Co-60, Sr-90, Cs-137 dan Am-241 sangat berbeda-beda ${ }^{[5]}$. Menurut Bunci ${ }^{[6]}$, radionuklida yang dikeluarkan oleh ledakan reaktor "Chernobyl" dan diadsorpsi dengan tanah organik jenis "saddy podzolic", didapat bahwa \% adsorpsinya berturut-turut $\mathrm{Cs}-137<\mathrm{Am}-241<\mathrm{Pu}-240<\mathrm{Sr}-90$, tetapi didalam tanah gambut $\mathrm{Cs}-137=\mathrm{Am}-241<\mathrm{Pu}-240<\mathrm{Sr}-90$. Adapun tujuan dari penelitian ini adalah, (1) melakukan pembuatan bahan adsorben dari hasil imobilsasi asam humat kedalam mineral bentonit, (2) karakteristik bentonit-asam humat dengan spektroskopi infra merah dan difraktometer sinar-X, dan ke (3) aplikasi adsorpsi Am-241, Cs-137, dan Sr-90 pada berbagai pH. Mineral bentonit dipilih karena banyak tersebar dalam jumlah besar di pulau Jawa, sedangkan asam humat mudah di isolasi dari tanah gambut Sumatra atau Kalimantan. Peneliti tertarik dengan radionuklida Am-241, Cs-137, dan Sr90, karena umur paro yang lama dan berbahaya bagi manusia.

\section{METODE PENELITIAN}

\section{Bahan}

$\mathrm{HCl}$ dan $\mathrm{HNO}_{3}$ pekat, $\mathrm{NaNO}_{3}, \mathrm{Am}\left(\mathrm{NO}_{3}\right), \mathrm{Cs}\left(\mathrm{NO}_{3}\right)$, dan $\operatorname{Sr}\left(\mathrm{NO}_{3}\right)$, calsium asetat, $\mathrm{NaOH}$ masing-masing buatan E Merck. Gas Nitrogin, Asam humat (koloid lignit), Bentonit asal Pacitan.

\section{Peralatan}

Seperangkat alat spektrometer $\gamma$ dan $\beta$ yang masing-masing dilengkapi detektor NaITl dan "Geiger Muhller", beserta MCA buatan EG dan G ORTEG 700 buatan Canberra, seperangkat alat penyaring vakum yang dilengkapi kertas saring Whatman 40, seperangkat alat spektromeri infra merah (FTIR) dan difraktometer sinar-X, pengaduk magnet dan wadah poliethilen kapasitas $50 \mathrm{~mL}$ dan perangkat lunak "Visual MINTEQ ver 2.3"

\section{Prosedur}

\section{Imobilisasi asam humat ke dalam bentonit}

Ke dalam gelas beker kapasitas $100 \mathrm{~mL}$ dimasukan berturut turut $60 \mathrm{gr}$ asam humat dan $40 \mathrm{~mL} \mathrm{NaOH} \mathrm{0,1} \mathrm{M} \mathrm{kemudian} \mathrm{diaduk} \mathrm{di} \mathrm{atas} \mathrm{pegaduk} \mathrm{magnit.}$ Kemudian kedalam gelas beker dimasukan 100 gr bentonit dan $10 \mathrm{~mL}$ $\mathrm{NaNO}_{3}$ 0,1 M dan selanjutnya diaduk selama 1 jam dan dibiarkan semalam. Disaring dengan kertas saring Whatman 40, endapan yang diperoleh dibilas dengan air suling dan dikeringkan pada suhu $60^{\circ} \mathrm{C}$ didalam oven selama \pm 3 
hari. Setelah endapan kering di analisis dengan spektromeri infra merah (FTIR) dan difraktometer sinar-X untuk mengetahui karakteristiknya.

\section{Penentuan gugus $\mathrm{COOH}$.}

Sebanyak $\pm 20 \mathrm{mg}$ hasil imobilisasi bentonit-asam humat dimasukkan kedalam erlenmayer $125 \mathrm{~mL}$, ditambahkan kedalamnya sebanyak $10 \mathrm{~mL}$ calsium asetat $0,2 \mathrm{~N}$ dan ditambahkan $40 \mathrm{~mL}$ air suling bebas $\mathrm{CO}_{2}$ (air yang telah dialiri gas nitrogin selama 2 jam) di kocok selama 24 jam. Endapan disaring dan dicuci dengan $20 \mathrm{~mL}$ air bebas $\mathrm{CO}_{2}$. Di pipet sebanyak $10 \mathrm{~mL}$ filtrat ke dalam gelas beker $50 \mathrm{~mL}$ dan dititrasi dengan larutan $\mathrm{NaOH} 0,1 \mathrm{~N}$ memakai alat potensiometer memakai elektroda glass. Titrasi dihentikan setelah $\mathrm{pH} 9(=\mathrm{T} \mathrm{mL})$. Dilakukan pengulangan terhadap blanko $(=\mathrm{B} \mathrm{mL})$. Sedangkan jumlah gugus karboksil dihitung dengan rumus :

\section{$\mathrm{COOH} /$ Gram Asam Humat $=(\mathrm{T}-\mathrm{B}) \times \mathrm{N} \times(1000 /$ Berat Asam Humat $)$}

Notasi $\mathrm{B}$ adalah mL.blangko, $\mathrm{T}$ adalah $\mathrm{mL}$ titran dan $\mathrm{N}$ adalah normalitas $\mathrm{NaOH}$.

Adsorpsi Am-241, Co-60, Cs-137 dan Sr-90 dalam bentonit-asam humat

Ke dalam wadah polietilen kapasitas $50 \mathrm{~mL}$ dimasukan bentonit-asam humat dengan sebanyak $0,01 \mathrm{~g}$ lalu dimasukkan berturut-turut ke dalamnya $2 \mathrm{~mL}$ larutan $\mathrm{HNO}_{3} 0,0001 \mathrm{M}, 0,8 \mathrm{~mL}$ larutan $\mathrm{NaNO}_{3} 0,01 \mathrm{M}, 13,2 \mathrm{~mL}$ aquades, larutan Am-241 atau Cs-137, atau Sr-90 dengan konsentrasi 0,001 mMol masing-masing sebanyak $4 \mathrm{~mL}$, sebelum wadah ditutup rapat $\mathrm{pH}$ di atur 4 . Masing-masing campuran dikocok selama satu jam dan didiamkan semalam. Selanjutnya masing-masing filtratnya dipisahkan dengan kertas saring Whatman 40 dan selanjutnya filtrat dicacah dengan spektrometer- $\gamma$ untuk Am-241 dan Co-60 sedangkan Sr-90 dengan spektrometer- $\beta$.

\section{HASIL DAN PEMBAHASAN}

\section{Optimasi Imobilisasi Asam Humat Ke dalam Bentonit}

Asam humat sering disebut asam polikarboksilat, karena kaya akan gugus fungsional karboksilat $(\mathrm{R}-\mathrm{COOH})$ sedangkan bentonit berupa padatan memiliki gugus aktif silanol (S-OH). Sehingga mekanisme reaksi pengikatan atau imobilisasi asam humat kedalam mineral bentonit diperkirakan dapat terjadi melalui adsorpsi spesifik melalui pertukaran ligand dengan terprotonasinya permukaan gugus $\mathrm{COOH}$ pada asam humat ${ }^{[7]}$. Untuk mengetahui keberhasilan imobilisasi tersebut, dapat dilakukan dengan menentukan jumlah gugus $\mathrm{COOH}$ yang telah terikat pada bentonit dengan 
cara titrasi potensiometri memakai $\mathrm{NaOH}$ sebagai titran dengan metoda calsium asetat ${ }^{[8]}$.

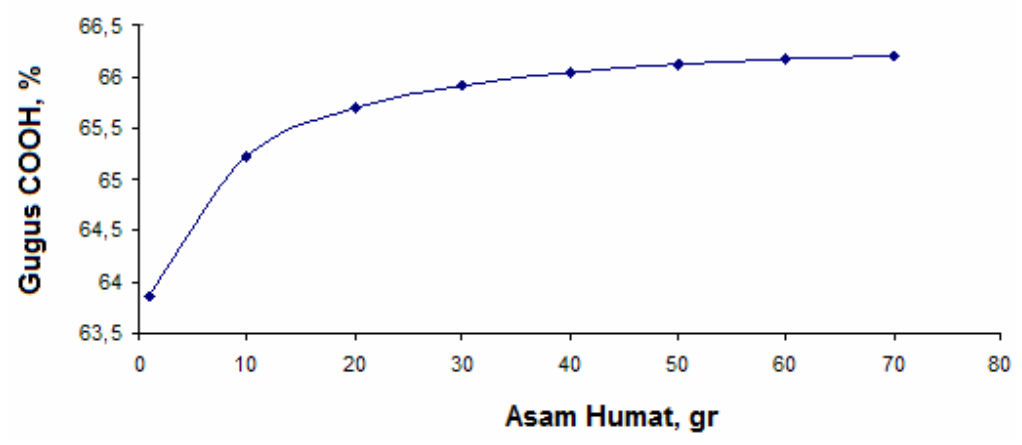

Gambar 1. Pengaruh Berat Terhadap Imobilisasi Asam Humat dalam Bentonit

Pada Gambar 1 dapat diperlihatkan bahwa semakin banyak asam humat yang ditambahkan kedalam bentonit, akan mengakibatkan meningkatan gugus $\mathrm{COOH}$ kedalam bentonit. Peningkatan persen gugus $\mathrm{COOH}$ tersebut akan relatif konstan pada berat asam humat sebanyak 60 gr. Jadi pada proses imobilisasi tersebut dengan umpan 100 gr bentonit, $\mathrm{pH}$ 2,5 dan kuat ion 0,0001 $\mathrm{M} \mathrm{NaNO}_{3}$, ternyata akan mengikat asam humat sebanyak 60 gr. Dari bentuk pola pada Gambar 1 tersebut, kemungkinan besar fenomena imobilisasi asam humat kedalam bentonit tersebut berupa adsorpsi isotherm. Asumsi ini ternyata tidak bertentangan dengan penelitian sebelumnya Kretzschmar $^{[7]}$ pada adsorpsi asam humat kedalam kaolinite dan Muzakky ${ }^{[0]}$ terhadap adsorpsi asam humat pada permukaan $\gamma-\mathrm{Al}_{2} \mathrm{O}_{3}$, ternyata sorpsi asam humat kedalam beberapa permukaan mineral atau oksida berdasarkan adsorspsi isoterm Langmuir. Mekanisme pengikatan asam humat kedalam beberapa mineral tersebut dapat melalui beberapa cara seperti ikatan elektrostatik, spesifik adsorpsi melalui pertukaran ligand hidroksil, jembatan kation dan adsorpsi hidrophobik pada muatan netral dari beberapa bagian makromolekul asam humat ${ }^{[7]}$.

Menurut Tombacz ${ }^{[10]}$ interaksi antara asam humat dengan beberapa mineral oksida akan dipengaruhi oleh $\mathrm{pH}$ dan kekuatan ion. Pada Gambar 2, dapat diperlihatkan pengaruh imobilisasi asam humat kedalam bentonit pada rentang pH 1 sampai 9. Dari Gambar 2 tersebut dapat diperlihatkan bahwa gugus hidroksida $(\mathrm{COOH})$ dari asam humat pada permukaan bentonit paling tinggi pada $\mathrm{pH} 2-2,5$. Selanjutnya setelah $\mathrm{pH} 3$ gugus $\mathrm{COOH}$ yang dapat terikat mulai menurun, dan pada $\mathrm{pH} 9$ hasil imobilisasi asam humat pada bentonit tidak terdapat gugus $\mathrm{COOH}$. 
Jadi pada proses imobilisasi tersebut dengan umpan 100 gr bentonit, asam humat 60 gr dan kuat ion $0,0001 \mathrm{M} \mathrm{NaNO}_{3}$, ternyata optimum pada $\mathrm{pH}$ 2,5 dan mampu mengikat gugus $\mathrm{COOH}$ sebesar $75 \%$ dari asam humat.

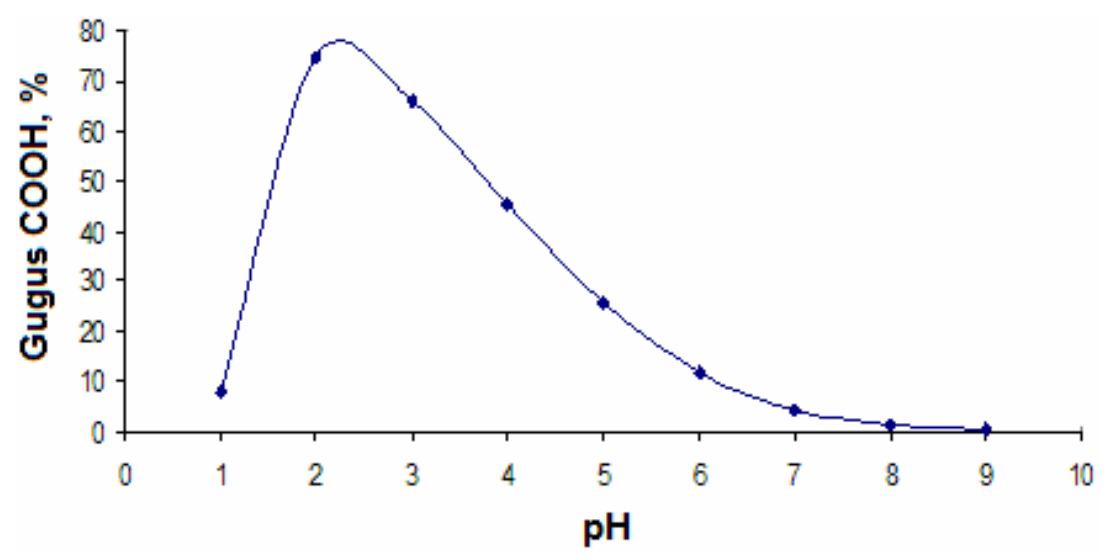

Gambar 2. Pengaruh pH Terhadap Imobilisasi Asam Humat Dalam Bentonit $^{[6]}$

Kondisi pada $\mathrm{pH}$ 2,5 tersebut adsorpsi asam humat pada permukaan bentonit akan diperkirakan optimum, hal ini kemungkinan disebabkan naiknya kekuatan ikatan elektrostatik antara asam humat dengan muatan positif pada permukaan bentonit. Pada $\mathrm{pH}$ 2,5 muatan negatif pada asam humat menjadi dominan, sehingga akan lebih mudah teradsorpsi kedalam permukaan bentonit $^{[10]}$. Menurut Kretzschmar ${ }^{[7]}$ pada $\mathrm{pH}$ rendah gugus funsional asam humat akan lebih terprotonasi dan konfigurasi makromolekul akan berubah dari polymer yang fleksibel menjadi konfigurasi tipe coil yang acak, akibatnya adsorpsi kedalam mineral oksida menjadi naik. Kemudian Pada Gambar 3, dapat diperlihatkan pengaruh imobilisasi asam humat kedalam bentonit pada berbagai kekuatan ion dalam hal ini adalah konsentrasi $\mathrm{NaNO}_{3}$. Dari Gambar 3 tersebut dapat diperlihatkan bahwa gugus hidroksida $(\mathrm{COOH})$ dari asam humat pada permukaan bentonit naik dari 0,0001 $\mathrm{M}$ menjadi 0,1 $\mathrm{M}$ $\mathrm{NaNO}_{3}$ dan relatif konstan pada $1 \mathrm{M} \mathrm{NaNO}_{3}$. Menurut Kretzschmar ${ }^{[7]}$ pada konsentrasi ion $\mathrm{Na}^{+}$tinggi, akan menaikan jembatan kation dan merubah konfigurasi makromolekul asam humat. Hal ini akan mengakibatkan adsorpsi asam humat kedalam bentonit menjadi naik. Jadi pada proses imobilisasi tersebut dengan umpan 100 gr bentonit, asam humat 60gr, pH 2,5 ternyata optimum pada kuat ion $0,1 \mathrm{NaNO}_{3}$ dan mampu mengikat gugus $\mathrm{COOH}$ sebesar $67,1 \%$ bagian dari asam humat. 


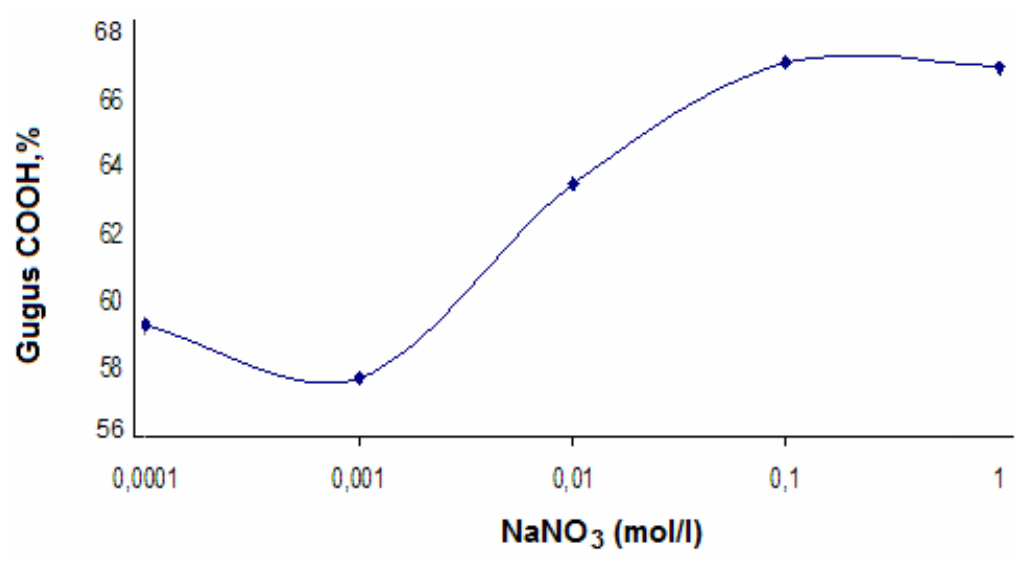

Gambar 3. Pengaruh $\mathrm{NaNO}_{3}$ Terhadap Imobilisasi Asam Humat dalam Bentonit

\section{Karakterisasi Bentonit-Asam Humat}

Setelah melalui tahapan pengeringan untuk menghilangkan sebagian besar kadar air, hasil imobilisasi bentonit-asam humat dilakukan perbandingan karakteristik gugus fungsionalnya dengan asam humat dan bentonit memakai alat spektroskopi infra merah dan difraktometer sinar-X. Dari data spektrum infra merah ternyata asam humat seperti ditunjukkan paada Gambar 4A dapat diindikasikan memiliki gugus-gugus fungsi yang memungkinkan untuk dapat berinteraksi dengan beberapa mineral oksida secara kimiawi. Hal tersebut dapat ditunjukkan pada Gambar 4A. Gugus-gugus fungsi tersebut seperti munculnya pita serapan pada $3402,2 \mathrm{~cm}^{-1}$ yang tajam dan melebar menunjukkan adanya gugus $-\mathrm{OH}$ asam karboksilat, serapan pada bilangan gelombang 3255,6 $\mathrm{cm}^{-1}$ merupakan vibrasi OH fenol, pita $2920,0 \mathrm{~cm}^{-1}$ vibrasi alur C-H alifatik, dan $2850,6 \mathrm{~cm}^{-1}$ adalah menunjukan gugus metilen. Vibrasi tekuk $\mathrm{OH}$ dan $\mathrm{C}-\mathrm{O}$ dari $\mathrm{COOH}$ ternyata diperkuat serapan pada bilangan gelombang $1114,8 \mathrm{~cm}^{-1}$ dan $2345,3 \mathrm{~cm}^{-1}$. Spektra-spektra serapan pada bilangan gelombang di atas ternyata sesuai dengan hasil dari $\operatorname{Tan}^{[8]}$ tentang karakteristik infra merah asam humat.

Kemudian untuk spektra infra merah bentonit Gambar 4B, terlihat pita serapan yang lebar pada bilangan gelombang $3431,1 \mathrm{~cm}^{-1}$, pita tajam pada $1637,5 \mathrm{~cm}^{-1}$, pita lebar pada $1028,0 \mathrm{~cm}^{-1}$, dan pita tajam pada $3622,1 \mathrm{~cm}^{-1}$ dan $916,1 \mathrm{~cm}^{-1}$. Spektra-spektra serapan bilangan gelombang tersebut ternyata sesuai dengan hasil spectra infra merah dari mineral montmorilonit oleh $\operatorname{Tan}^{[8]}$ yang menunjukkan pita daerah sekitar $3420 \mathrm{~cm}^{-1}$ untuk vibrasi $\mathrm{OH}$ dan pita lebar pada $1050 \mathrm{~cm}^{-1}$ untuk vibrasi $\mathrm{Si}-\mathrm{O}$, pita tajam pada bilangan gelombang $3622 \mathrm{~cm}^{-1}$ untuk vibrasi ulur $\mathrm{OH}$ bebas dan pita tajam pada 
bilangan gelombang 1637,5 merupakan vibrasi lentur $\mathrm{OH}$ dari molekul air serta pita tajam pada bilangan gelombang $910-920 \mathrm{~cm}^{-1}$ untuk getaran $\mathrm{Al}-\mathrm{O}$.

Kemudian untuk spektra infra merah hasil imobilisasi bentonit-asam humat Gambar 4C, terlihat pita serapan yang sedikit berbeda dengan spektra infra merah bentonit 4B. Hal ini terlihat dengan munculnya serapan pada panjang gelombang $2923,9 \mathrm{~cm}^{-1}$ sebagai vibrasi alur C-O alifatik dan 2852,4 $\mathrm{cm}^{-1}$ yang merupakan karakteristik dari vibrasi gugus metilen. Hasil ini menandakan bahwa asam humat akan teradsorpsi kedalam mineral benonit, selanjutnya dengan munculnya serapan pada bilangan gelombang 1035,7 yang melebar dapat diartikan terjadinya kristalisasi bentonit akibat mengadsorpsi asam humat.

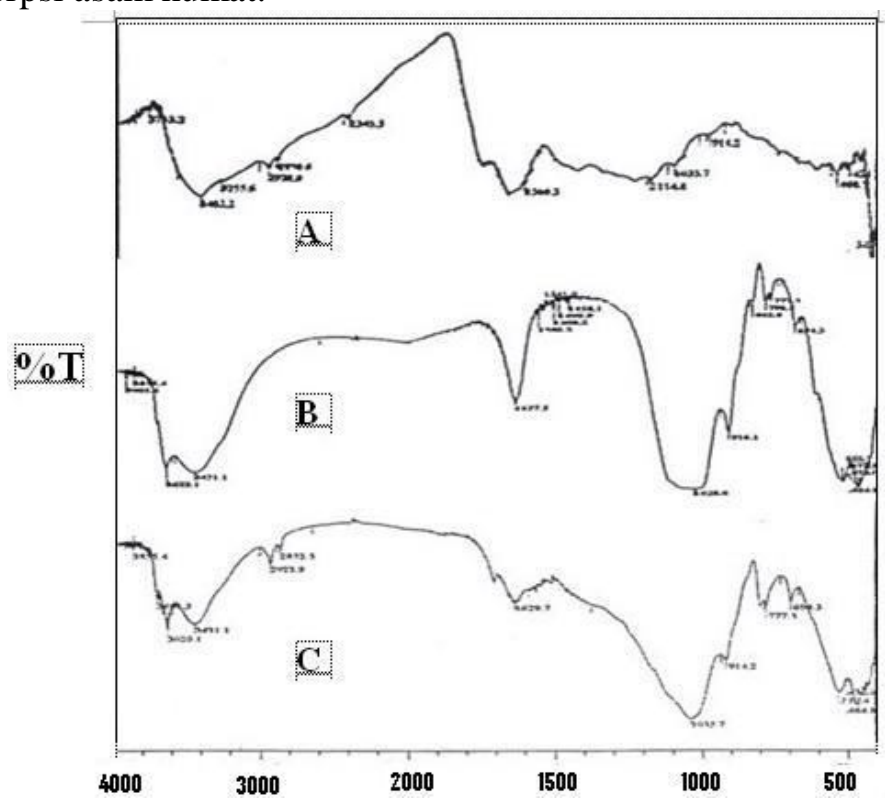

Gambar 4. Spektra Infra Merah Asam Humat 4A, Bentonit 4B dan Bentonit-Asam Humat 4C

Karakterisasi asam humat, bentonit dan hasil imobilisasi asam humat dalam bentonit dengan alat difraktometer Sinar-X dapat dilihat pada Gambar 5. Pada Gambar 5A diperlihatkan difraktometer Sinar-X untuk asam humat dengan puncak tertinggi pada sudut difraksi $2 \theta$ sebesar $11,64^{\circ}$ dengan intensitas puncak sangat signifikan. Data ini mengindikasikan kedudukan detektor pada posisi sudut difraksi $2 \theta$ sebesar $11,64^{\circ}$ menerima pancaran sinar-X hasil difraksi oleh padatan asam humat dengan frekuensi sinar- $X$ yang didefraksi relative sangat tinggi. Intensitas puncak ini terjadi disebabkan oleh banyaknya "Systimatically Absent Reflection (SAR)" pada padatan asam 
humat yang terkena sinar-X pada kedudukan detector menempati posisi sudut difraksi $2 \theta$ sebesar $11,64^{\circ}$.

Kemudian pada Gambar 5A, juga dapat diperlihatkan difraktogram asam humat memperlihatkan puncak-puncak difraksi yang berekor, hal ini menunjukkan bahwa padatan asam humat cenderung berbentuk amorf atau tingkat kristalinitas padatannya cenderung rendah. Fenomena ini kemungkinan karena ikatan hydrogen antar gugus fungsi yang terdapat pada struktur senyawa asam humat, terbukti dengan puncak difraksinya yang memiliki resolusi relatif tinggi.

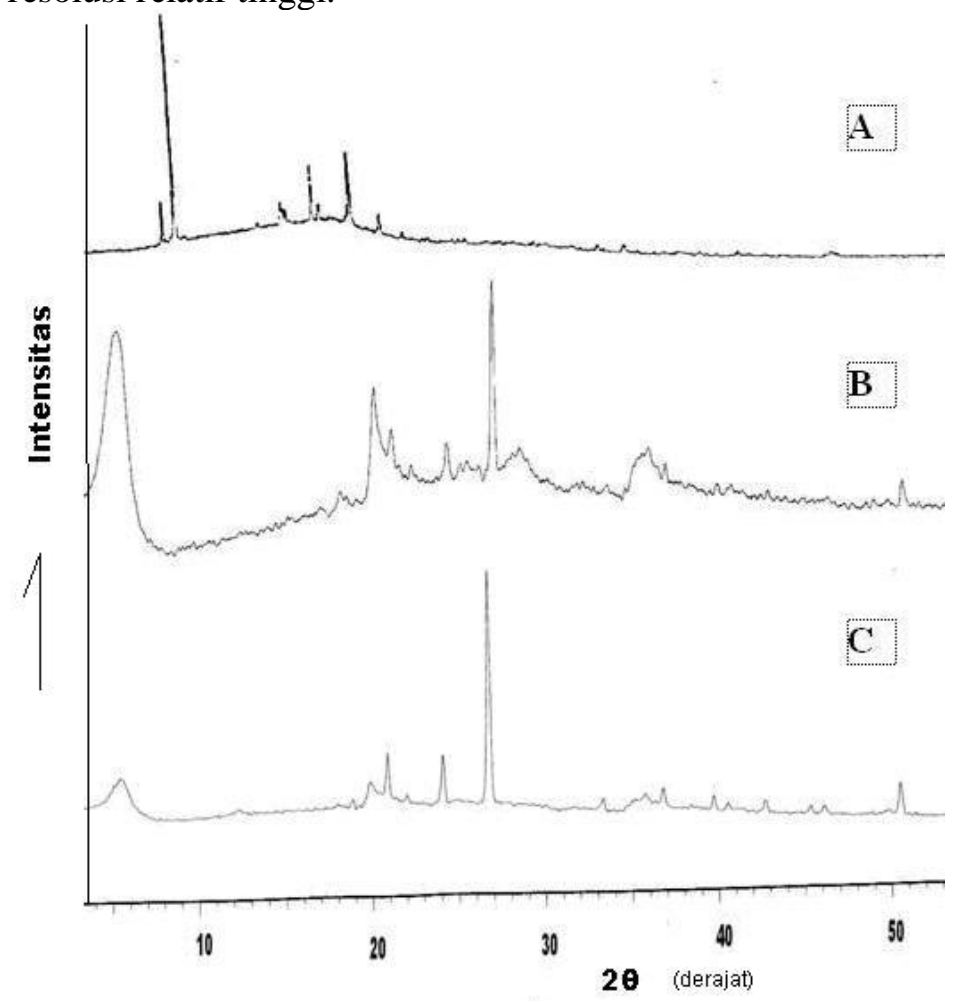

Gambar 5. Difraktogram XRD Asam Humat 5A, Bentonit 5B dan Bentonit-Asam Humat 5C

Difraktogram bentonit Gambar 5B terdapat puncak-puncak tertinggi pada sudut difraksi $2 \theta$ sebesar $26,65 \mathrm{~A}^{\circ}$ dengan intensitas puncak yang cukup, hal ini berarti detektor menerima difraksi sinar-X dari bentonit paling kuat intensitasnya. Berdasarkan tabel "Mineral Powder Difraction File (MPDF)" difraksi tersebut menunjukkan adanya mineral quarsa. Demikian pula pada sudut difraksi $2 \theta$ sebesar $5,1023 \mathrm{~A}^{\mathrm{o}}$ yang setara dengan kisi kristal (d) sebesar $17,30 \mathrm{~A}^{\circ}$ yang mengindikasikan adanya mineral monmorillonit. Walaupun tidak kecil juga terlihat intensitas difraksi $2 \theta$ sebesar $19,89 \mathrm{~A}^{\circ}$ 
yang setara dengan $d=4,466 \mathrm{~A}^{\circ}$, yang merupakan penciri mineral kaolinit. Berdasarkan difraktogram tersebut dapat menunjukan bahwa padatan bentonit cenderung berbentuk amorf.

Selanjutnya hasil difraktogram hasil imobilisasi asam humat kedalam bentonit (bentonit-asam humat) pada Gambar 5C, menunjukkan adanya puncak tertinggi pada sudut $2 \theta$ sebesar $26,65 \mathrm{~A}^{\circ}$ yang identik dengan sudut difraksi pada difraktogram bentonit. Pada sudut $2 \theta$ sebesar $26,65 \mathrm{~A}^{\circ}$ tersebut bentonit-asam humat intensitasnya lebih kuat, hal ini kemungkinan telah terjadinya adsorpsi asam humat pada mineral quarsa, pada mineral Dikit ( $2 \theta$ $=20,80)$, dan pada mineral paligorskit $(2 \theta=23,97)$. Pada Gambar 5C secara keseluruhan difraktogram bentonit-asam humat terjadi kenaikan intensitas di beberapa sudut difraksi, yang mengindikasikan adanya imobilisasi asam humat kedalam bentonit cukup baik. Selanjutnya Pada Gambar 5C telah terjadi pergeseran sudut difraksi seperti dari $2 \theta=5,10$ menjadi 5,52. Pergeseran ke arah kanan, kemungkinan disebabkan adanya asam humat yang teradsorpsi pada mineral monmorillonit.

\section{Adsorpsi Am-241, Co-60, Cs-137 dan Sr-90 dalam Bentonit-Asam Humat}

Sebagai perbandingan hasil imobilisasi bentonit-asam humat dengan bentonit yang diaplikasikan untuk adsorpsi radionuklida Am-241, yang hasilnya dapat diperlihatkan pada Gambar 6.

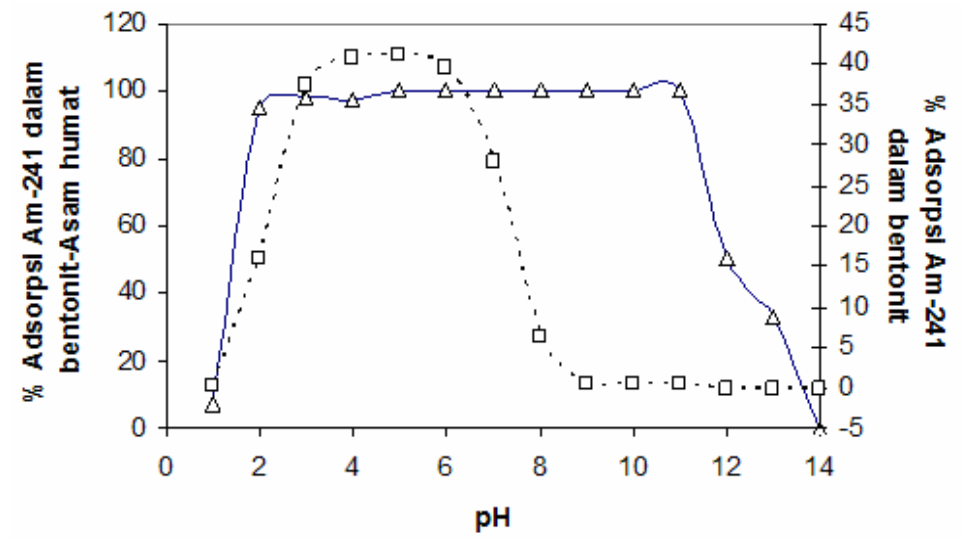

$\triangle$ Am-241 (dalam bentonit-as am humat) $\cdots . \square \cdot \cdots$ Am-241 (dalam bentonit)

Gambar 6. Aplikasi Imobilisasi Bentonit-Asam Humat dan Betonit Pada Adsorpsi Am-241

Dari Gambar 6, dapat diperlihatkan bahwa adsorpsi radionuklida Am-241 kedalam bentonit-asam humat dapat berlangsung baik dengan adsorpsi 99,95 $\%$, di sepanjang $\mathrm{pH} 2$ hingga $\mathrm{pH}$ 11, kemudian setelah $\mathrm{pH} 12$ hingga $\mathrm{pH} 14$ 
adsorpsi akan turun. Sedangkan adsorpsi Am-241 kedalam bentonit hanya terjadi pada kisaran $\mathrm{pH}$ 2,5 hingga $\mathrm{pH}$ 6, dengan hasil maksimum adsorpsi sebesar $40.95 \%$ selanjutnya setelah $\mathrm{pH} 7$ adsorpsi turun bahkan pada $\mathrm{pH}$ di atas 9 Am-241 bahkan tidak ada yang teradsorpsi. Fenomena desorpsi Am241 selanjutnya di simulasikan dengan perangkat lunak "Visual minteq" ${ }^{\text {"11] }}$, guna mengetahui sifat-sifat Am-241 pada $\mathrm{pH}$ tinggi. Dengan masukan konsentasi 0,001 mMol Am-241, 0,01 M kuat ion, suhu $25^{\circ} \mathrm{C}$, hasil keluaran "Visual minteq" didapat diperlihatkan pada Gambar 7. Ternyata pada Gambar 7 dapat ditunjukan bahwa, Amerisium pada $\mathrm{pH} 1$ - 14 mempunyai beberapa spesies hidroksida seperti ion $\mathrm{Am}(\mathrm{OH})_{2}{ }^{+}, \mathrm{Am}(\mathrm{OH})^{2+}$ dan $\mathrm{Am}(\mathrm{OH})_{3}$ (aq) yang bersifat larut dalam air.

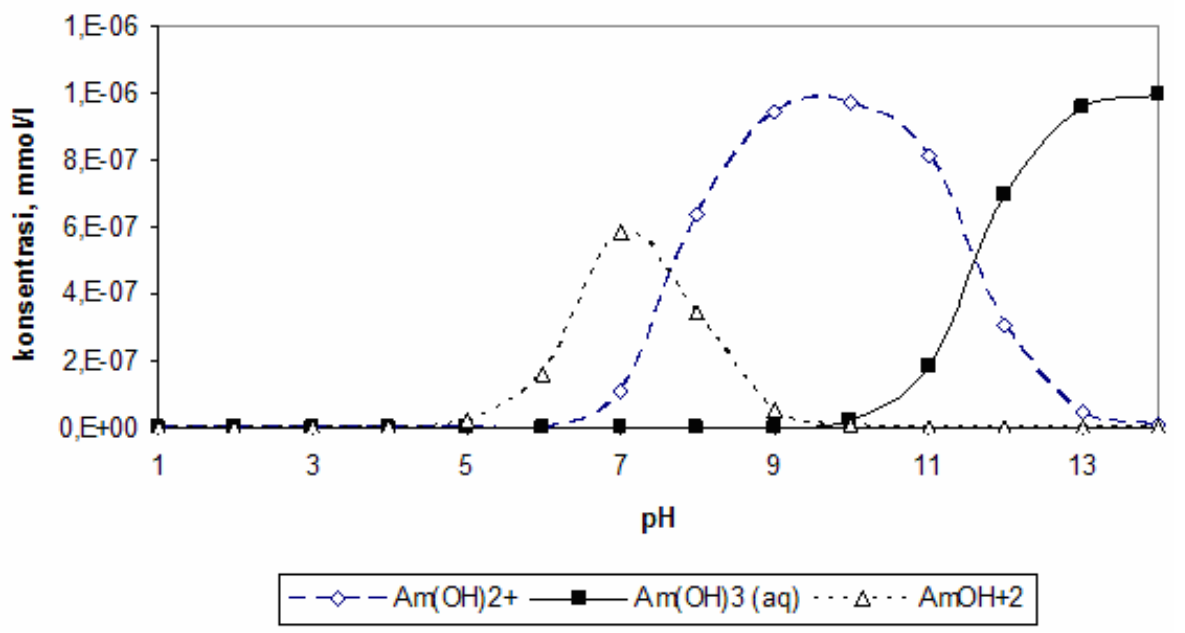

Gambar 7. Beberapa Spesies Hidroksida Amerisium Pada Beberapa pH (Simulasi Dengan "Visualminteq")

Dengan terbentuknya spesies-spesies terebut dapar dimengerti mengapa Am241 yang telah terikat pada kedalam permukaan bentonit-asam humat, mengalami desorpsi kembali kedalam larutan. Sedangkan Am-241 akan segera terdesorpsi kedalam larutan, karena $\mathrm{pH} 6$ telah terjadi spesies hidroksida $\mathrm{Am}(\mathrm{OH})_{2}{ }^{+}$yang tidak mampu diikat oleh permukaan bentonit. 


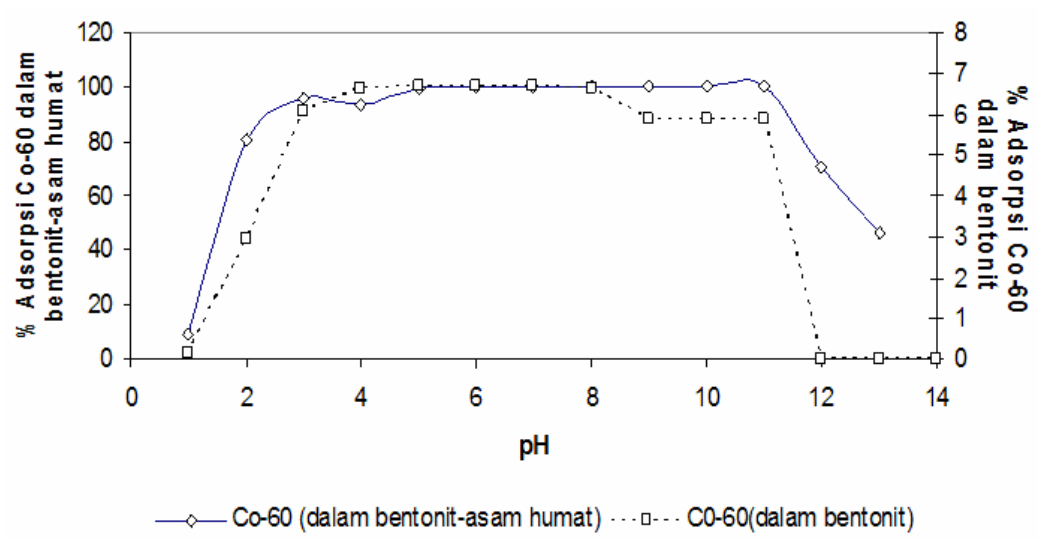

Gambar 8. Aplikasi Imobilisasi Bentonit-Asam Humat dan Betonit Pada Adsorpsi Co-60

Selanjutnya pada Gambar 6, dapat ditunjukan bahwa adsorpsi Co-60 dalam bentonit asam- humat dan bentonit akan terjadi pada $\mathrm{pH} 3$ hingga $\mathrm{pH} 11$, dengan 96,5\% - 99,8\% adsorpsi untuk Co-60 dalam bentonit-asam humat sedangkan $5,5 \%-6,8 \%$ adsorpsi dalam bentonit. Selanjutnya setelah pada kondisi $\mathrm{pH} \mathrm{12,} \mathrm{adsorpsi} \mathrm{Co-60} \mathrm{baik} \mathrm{itu} \mathrm{dalam} \mathrm{bentonit-asam} \mathrm{humat} \mathrm{atau}$ bentonit akan cenderung turun.

Fenomena ini ternyata pada kondisi $\mathrm{pH}$ tinggi terjadi terbentuknya spesies hidroksida cobal seperti $\mathrm{Co}(\mathrm{OH})_{2}(\mathrm{aq}), \mathrm{Co}(\mathrm{OH})_{3}, \mathrm{CoOH}^{+}$dan $\mathrm{Co}_{4}(\mathrm{OH})_{4}{ }^{+4}$ seperti yang terlihat pada Gambar 9. Spesies-spesies tersebut merupakan hasil keluaran simulasi memakai perangkat lunak "Visual minteq" [11], dengan masukan konsentasi 0,001 mMol Co-60, 0,01 M kuat ion, suhu $25^{\circ} \mathrm{C}$.

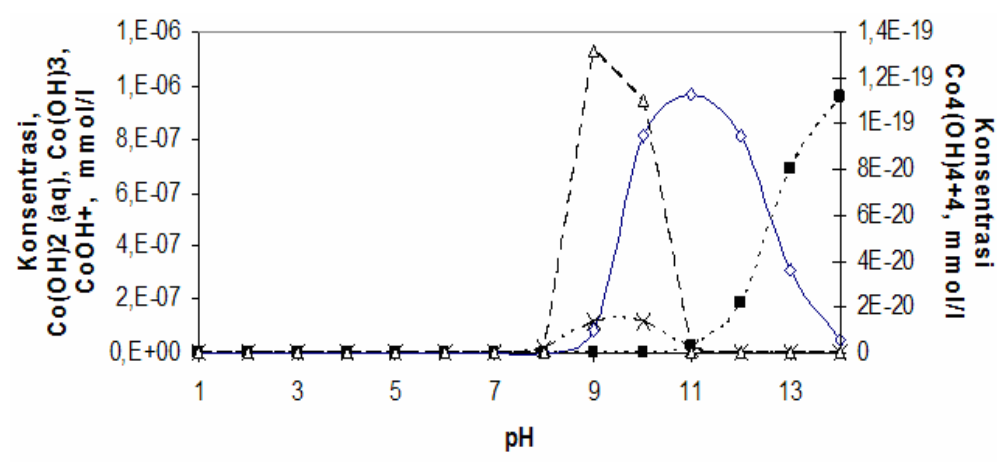

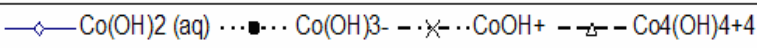

Gambar 9. Beberapa Spesies Hidroksida Cobal Pada Beberapa pH (Simulasi dengan "Visualminteq") 
Pada Gambar 9 tersebut, dapat diperlihatkan bahwa di daerah $\mathrm{pH} 12$ dan $\mathrm{pH}$ 13, didominisasi oleh spesies $\mathrm{Co}(\mathrm{OH})_{2}(\mathrm{aq})$ dan $\mathrm{Co}(\mathrm{OH})_{3}$ akibatnya Co-60 akan terlepas kedalam larutan beserta asam humat yang telah termobilisasi kedalam permukaan bentonit.

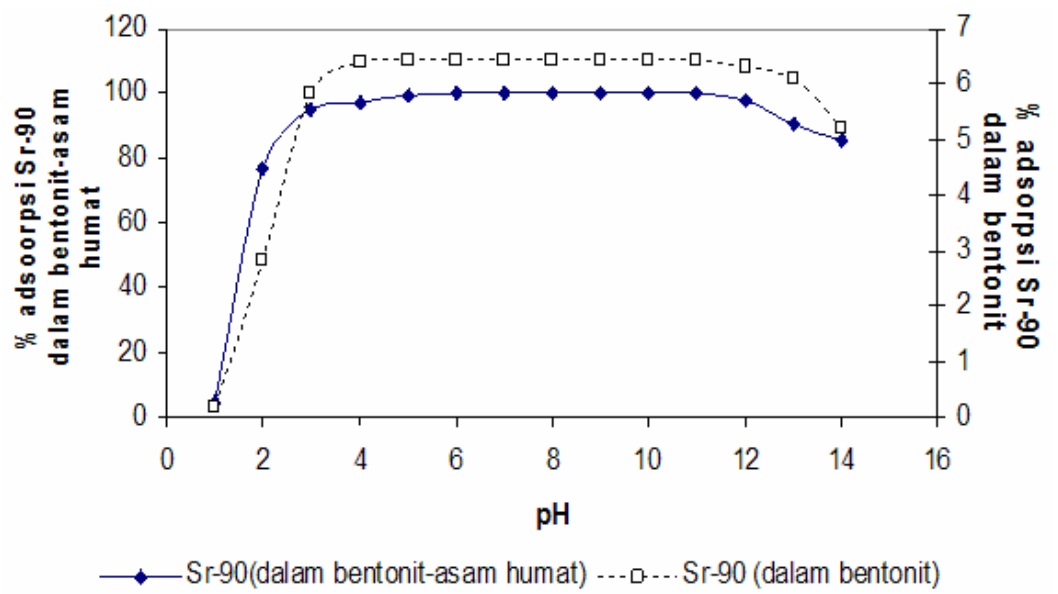

Gambar 10. Aplikasi Imobilisasi Bentonit-Asam Humat dan Betonit Pada Adsorpsi Sr-90

Dari Gambar 10, dapat diperlihatkan bahwa adsorpsi radionuklida Sr-90 kedalam bentonit-asam humat dapat berlangsung di sepanjang $\mathrm{pH} 2$ hingga pH 11. Pada Ganbar 10 dapat diperlihatkan bahwa perbandingan adsorpsi Sr90 dalam bentonit-asam humat berharga 96,87\% - 99,56\%, sementara bentonit hanya 5,81\%-6,45\%. Kemudian setelah $\mathrm{pH} 12$ hingga $\mathrm{pH} 14$ adsorpsi Sr-90 baik itu dalam bentonit-asam humat dan bentonit akan cenderung turun. Untuk mengetahui fenomena desorpsi Sr-90 tersebut juga disimulasikan dengan perangkat lunak "Visual minteq", guna mengetahui sifat-sifat Sr-90 pada $\mathrm{pH}$ tinggi. Dengan masukan konsentasi 0,001 $\mathrm{mMol} \mathrm{Sr}-$ 90, 0,01 M kuat ion, suhu $25^{\circ} \mathrm{C}$, hasil keluaran "Visual minteq" dapat diperlihatkan pada Gambar 11. Pada Gambar 11 tersebut, ternyata hanya terdapat satu buah spesies stronsium hidroksida yanitu $\operatorname{Sr}(\mathrm{OH})^{+}$. 


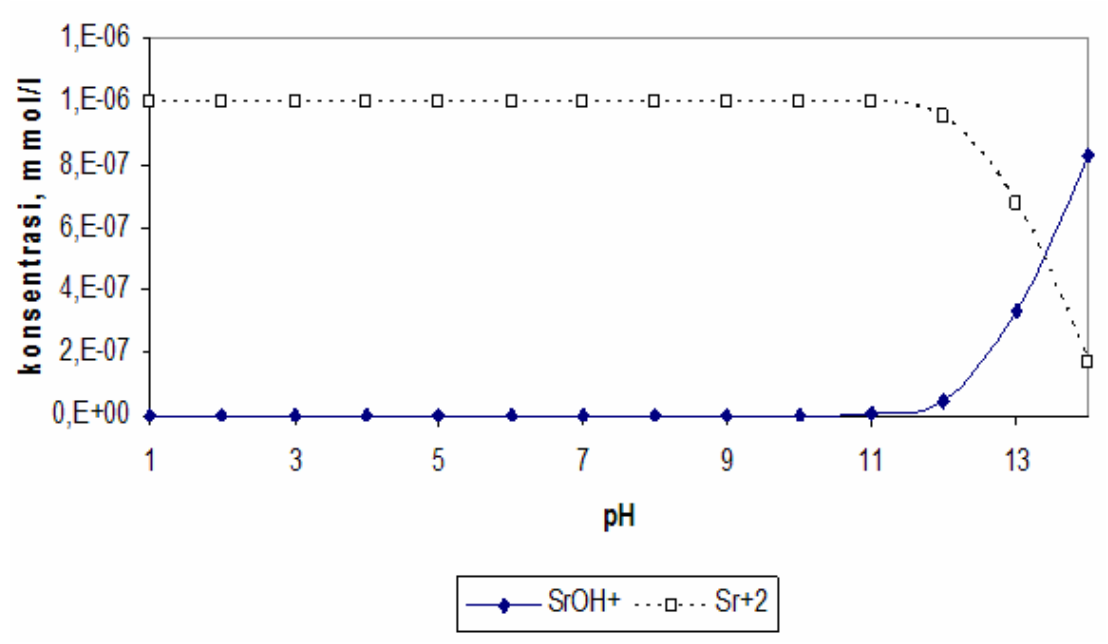

Gambar 11. Beberapa Spesies Hidroksida Sronsium Pada Beberapa pH (Simulasi Dengan "Visualminteq")

Pada Gambar 11 dapat ditunjukan bahwa pada daerah $\mathrm{pH} 12-\mathrm{pH} 13 \mathrm{Sr}^{2+}$ yang dapat diikat oleh hasil imobilisasi bentonit-asam humat dan bentonit akan semakin turun, seiring dengan terbentuknya spesies hidroksida $\operatorname{Sr}(\mathrm{OH})^{+}$. Maka pada keadaan $\mathrm{pH}>12 \mathrm{Sr}-90$ akan masuk kembali kedalam larutan dan terlepas dari permukaan bantonit-asam humat.

\section{KESIMPULAN}

Imobilisasi bentonit-asam humat dapat dilakukan dengan umpan $100 \mathrm{~g}$ bentonit, asam humat $60 \mathrm{~g}$, kuat ion $0,1 \mathrm{M} \mathrm{NaNO}_{3}, \mathrm{pH} 2,5$ dimana pada kondisi tersebut dapat mengikat gugus $\mathrm{COOH}$ masimum sebesar 75,2\%. Berdasarkan data spektroskopi infra merah dan difraktometer sinar-X, asam humat dapat termobilisasi kedalam bentonit membentuk paduan bentonitasam humat. Aplikasi adsorpsi radionuklida Am-241, Cs-137 dan Sr-90, menunjukan bahwa bentonit-asam humat dapat mengadsorpsi dengan rentang pH 3 hingga pH 10. Dengan umpan radionuklida Am-241, Cs-137 dan Sr-90 masing-masing $0,001 \mathrm{mMol} / \mathrm{l}$, kuat ion ion $0,1 \mathrm{M}$ dan $\mathrm{pH} 5$ ternyata bantonitasam humat dapat mengadsorpsi $98,50 \%-99,1 \%$

\section{DAFTAR PUSTAKA}

1. KUMAR.A., SINGHAL.R.K ., PREETHA.J., et al., 2008., "Impact of Tropical Ecosystem on The Migrational Behavior of K-40, Cs-137, Th-232 ,U-238 in Perennial Plant", Water,Air, Soil Pollut, 192, 293-302. 
2. WHICKER,F.W., HINTON,T.G., and MACDONELL., 2004, "Avoiding Destructive Remediation”, Science., 303, 1615-1616.

3. CARVER.A.M., and HINTON.T.G., 2007., "Reduce Plant Uptake of Zr-95 Grown in Illite-Amended Sediments", Water Air Soil Pollut., 185, 255-263.

4. OLGA.N.A., and SCHULZ.M., 2008., "Estimation of The Influence Humic Acid on Radionuclide Binding to Soil Residuals in Deposites of Radioactive Waste", Water Air Soil Pollut, 194, 287-299.

5. CARON,F., LAURIN,S., and SIMISTER, C., 2007., "Potential Use of Ultrafiltration for Groundwater Remediation and Aqueous Speciation of Co-60 and Cs-137 from A Contaminated Area", Water Air Soil Pollut., 178, 121-130.

6. BUNZI.K., KRACKE.W., and TIKHOMIROV.A., 1998., "Association of Chernobyl-derived ${ }^{239+240} \mathrm{Pu},{ }^{241}-\mathrm{Am},{ }^{90} \mathrm{Sr}$ and ${ }^{137} \mathrm{Cs}$ with Different Molecular Size Fraction of Organic Matter in The Soil Solution of Two Grassland Soil", Radiat.Environ Biophys., 37, 195-200.

7. KRETZSCHMAR.R., and HESTERBERG.D., 1997., "Effects of Adsorbed Humic Acid on Surface Charge and Flocculation of Kaolinite", Soil.Sci.Soc Am.J., 61. 101-108.

8. TAN.K.H, 1996, Soil Sampling, Preparation, and Analysis, Marcel Dekker,Inc, New York.

9. MUZAKKY, and SRI JUARI SANTOSA., 2007, "Adsorpsi of Th-232 and U238 by $\gamma-\mathrm{Al}_{2} \mathrm{O}_{3}$-Humate at Single and Competitive Systems", Indo. J. Chem, 8 (2), 163-168.

10. TOMBACZ E., 2000, "Effect of $\mathrm{pH}$ and Ionic Strength on The Interaction of Humic Acic with Aluminium Oxide", colloid Polym Sci., 278., p.337-345

11. GUSTAFSSON.,J.P., 2008, “ Manual of Visual MINTEQ”. http://www.lwr.kth.se/Personal/personer/gustafsson_jon_petter/index.asp, 19 April . 
